\title{
石炭灰造粒物を用いた底質改善技術の検討 STUDY OF ENVIRONMENTAL QUALITY IMPROVEMENT TECHNOLOGY USING FLY ASH FOR CONSOLIDATED SEDIMENT
}

\author{
富田智 1 ・日比野忠史 2 -末國光彦 $3 \cdot$ 田多一史 ${ }^{4} \cdot$ 水野雅光 $^{5}$ \\ Satoshi TOMIDA, Tadashi HIBINO, Mitsuhiko SUEKUNI, \\ Kazufumi TADA,Masamitsu MIZUNO \\ 1正会員 日本ミクニヤ(侏) 環境防災部（テ734-0015 広島県広島市南区宇品御幸4-4-7） \\ 2 正会員 博士 (工学) 広島大学助教授 工学研究科（下739-8527 広島県東広島市鏡山1-4-1） \\ 3 正会員 中国電力侏) 土木部（厂730-8701 広島県広島市中区小町4-33） \\ 4 正会員 工修 中電技術コンサルタント侏) 臨海・都市部（テ734-8510 広島県広島市南区出汐 2-3-30） \\ 5 正会員 国土交通省中国地方整備局 太田川河川事務所 （干730-0013 広島県広島市中区八丁堀3-30）
}

\begin{abstract}
The organic mud moves with water flowing in estuary. It is carried to the river with flood tide, and settles on the river bed at a tidal flat. If the purification ability of the organic mud is small, the sludging of the tidal flat is accelerated. The organic mud settled there causes the environment deterioration and loss of waterside scene value.

The environmental quality improvement technology using fly ash for consolidated sediment is proposed. The large pore pipe made by fly ash is embedded in the consolidated mud on sand layer. It can cause the water movement in the pipe with the ebb and flood tide, and the water movement raises living thing habitation environment by supplying oxygen into consolidated mud.
\end{abstract}

Key Words : tidal range, pore water movement, organic mud, sediment improvement, benthos

\section{1.はじめに}

河川感潮域に発達する河岸干潟では, 洪水を経験しな い場合には, 河川上流のみならず海域から運搬される有 機泥が遡上・沈降する. 一旦干潟上に有機泥が堆積する と, 有機泥の流下は困難になり, 干潟の泥化が進行して いく. 干潟の泥化が進行すると, 底質内部の水循環が阻 害され, 栄養塩負荷の蓄積, 硫化物などの有害物質の堆 積など, 河川浄化能力が低下し, 生物生息環境の悪化が 起こるだけではなく, 水辺景観価值の大いなる損失に繋 がる. 堆積泥による環境悪化対策として浚渫が挙げられ るが, 浚渫後にも泥の堆積が継続することから, 大きな 費用対効果は期待できない. さらに, 浚渫土の処分も難 しくなってきており, 新たな堆積泥処理技術の開発が求 められている.

著者らは新しい底質改善技術として石炭灰造粒物を用 いた底質処理技術を提案し, 実証実験を行ってきた. 本 技術は, 石炭灰造粒物を用いて作成した浸透柱 (写真-1
参照)を有機泥（シルト・粘土）層の下に堆積する砂層 まで貫入し (図-1参照)，潮汐の干満を利用して浸透柱 内の水循環を生起させるものである. 水循環が起こるこ とにより堆積泥内に酸素を供給することができ, 生物生 息環境を向上させることで, 堆積泥処理を行うものであ る.

本論文では，石炭灰を用いた底質改善技術の有効性を 検討するために行った現地実証実験の結果について分析 し, 本技術による堆積泥の処理機構についてまとめてい る. 天満川（太田川市内派川）感潮域にある河岸干潟に 堆積した有機泥層（砂層上に堆積した層厚約 $40 \mathrm{~cm} の シ$

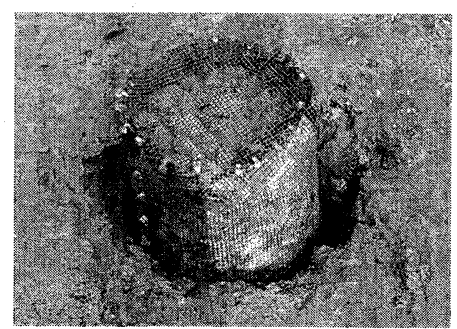

写真-1 浸透柱の設置状況 


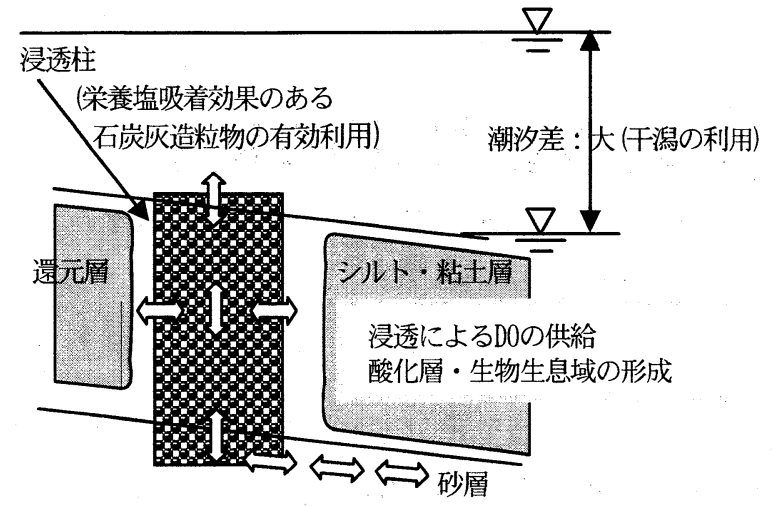

図-1 有機泥の対策方法

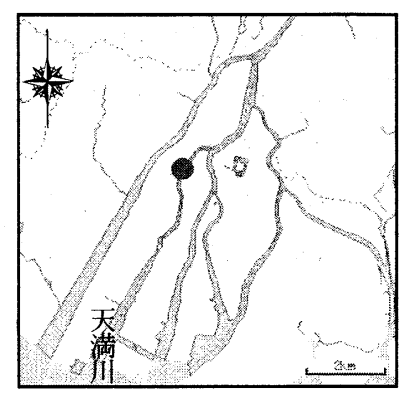

図-2 実験場所 (広島市内)

ルト・粘土層）に，石炭火力発電の副産物である栄養塩 を吸着できる石炭灰造粒物を利用して作製した浸透柱を 埋設し, 浸透柱内に流動が起こる機構と流動が周辺に及 ぼす効果について検討した。

\section{2. 石炭灰造粒物による底質改善技術の検討方法}

\section{（1）実験区域周辺の概要}

現地実験は，図-2に示す広島市の市街地を貫流する天 満川の距離標3K000地点で実施した.

実験区域周辺には，河床（横断形）の5割程度に干潟 が形成されている. 現状の干潟は, 泥干潟であるが, $40 \mathrm{~cm}$ 程度の厚さで堆積した有機泥層の下には砂が堆積 している. 堆積した有機泥層のシルト・粘土含有量 (図3参照) は, 深度0～15cmで約 $40 \%$, 深度 $15 \sim 35 \mathrm{~cm}$ で約 $13 \%$ あ゙あ. 浸透柱を設置した天満川は, 広島湾の朝汐 （大潮期約 $4 \mathrm{~m}$ の潮差）の影響を受ける感潮河川であり， 大潮満潮時には 30 を越える塩分の海水が遡上している

(後の図-11参照) . 図-4には, 平成16年6月〜平成17年 3月まで測定された海水遡上頻度を示している. 海水遡 上頻度は, 塩分 1 2 2゙最も多く $45 \%$ であり, 塩分 10 以下 で80\%以上を占めている。 また, 高塩分で32の塩水遡上 も確認されており, 塩分変動が大きい環境（季節によっ て異なる゙）であることがわかる.

\section{（2）現地実験の概要（浸透柱の設置方法）}

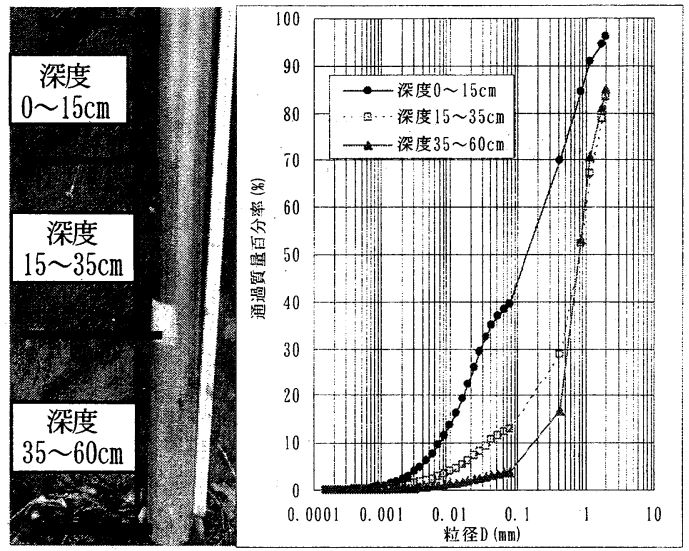

図-3＼cjkstart底質状況および粒度分布

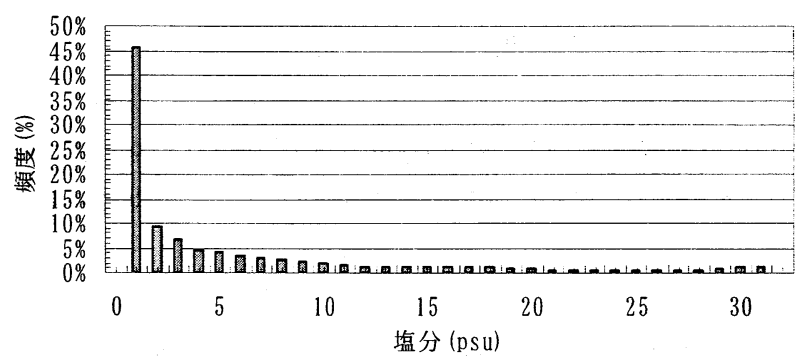

図-4 海水遡上頻度

本実験は，浸透柱の個々の底質改善の効果と配置法を 検討するために，平成16年5月に施工し，平成16年6月か ら平成17年3月までモニタリングを実施した．図-5に浸 透柱の設置位置と調査地点を示した. 実験区域の規模は, $4.0 \mathrm{~m} \times 2.5 \mathrm{~m}$ と, 浸透柱を計11本施設した. また, 実験 効果の比較を行うため, 実験区域内に浸透柱の影響が小 さいと想定される場所に比較区を設定した.

実験に用いた浸透柱は, 中国電力株)の加圧流動床式石 炭灰火力発電所から産出される石炭灰を原料とした造粒 物 (以下, 「石炭灰造粒物」という.) を網状の円筒（ $\phi$ $160 \mathrm{~mm}$ ，高さ $500 \mathrm{~mm}$ ）に詰めて作製した. 表-1に石炭 灰造粒物の化学成分および形状, 写真-2に石炭灰造粒物 を示す，ちなみに，石炭灰造粒物は，窒素およびリンの 吸着効果があり, 単体による底質改善効果も期待できる.

\section{（3）調査の種類と方法（図-5参照）}

\section{a) 底生生物調查 (2地点 : O印, 年4回)}

浸透柱周辺の生物の出現状況を 4 季節に確認した. 試 料は, $\phi 100 \mathrm{~mm}$ のパイプを用いて鉛直方向に $20 \mathrm{~cm}$ 程度 採取した. 採取試料は, 現地でフルイ (目合い: $1 \mathrm{~mm})$ が けし，フルイに残った試料を室内で同定した. 同定項目 として, 種の査定, 生物種類別個体数および湿重量を設 定した.

\section{b) 底質調査 (2地点 : O印，年4回)}

比較区の底質と浸透柱周りの底質を比較することで浸 透柱周辺の底質変化の状況を把握した. 試料は, $\phi$ $50 \mathrm{~mm}$ のパイプを用いて鉛直方向に $50 \mathrm{~cm}$ 程度採泥した. 採取試料は, 室内において粒度分析を行った。粒径 


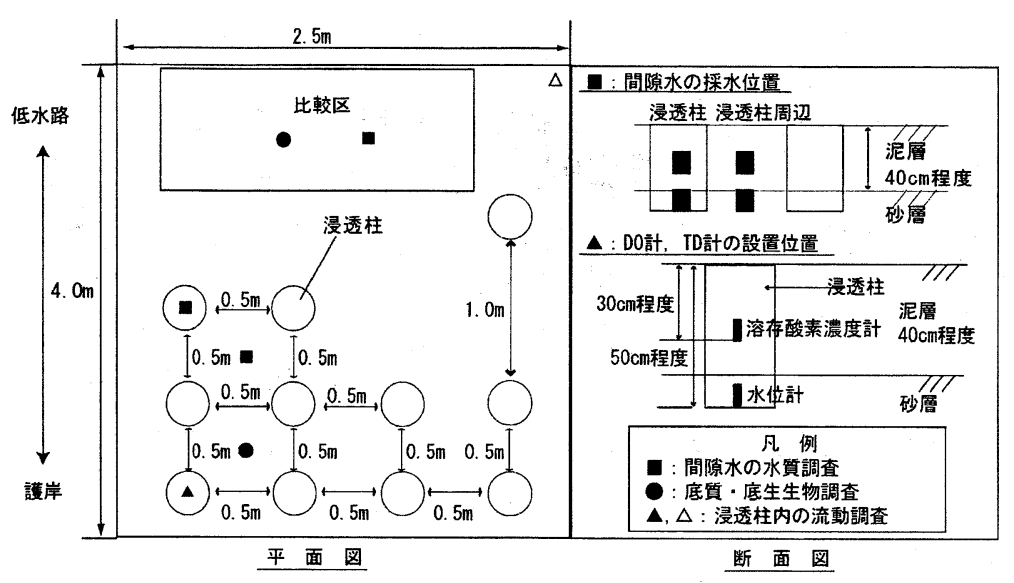

図-5 実験の概要 (浸透柱の設置要領と調査位置)

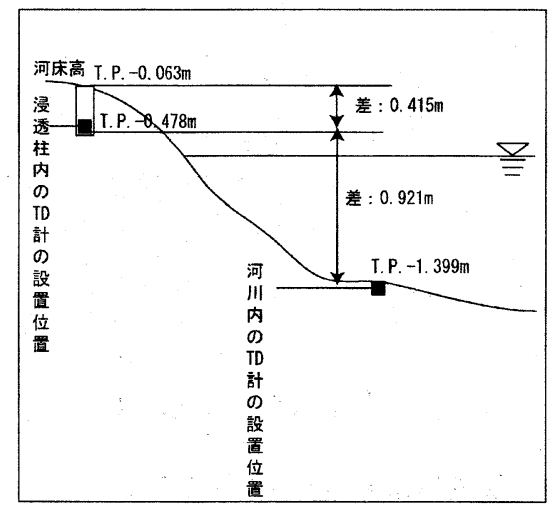

図-6 水位計 (TD計) の設置状況

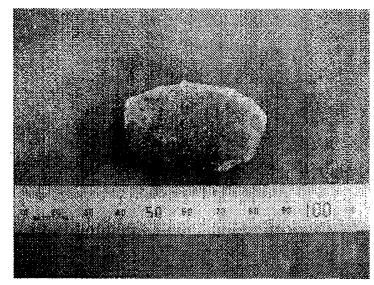

写真-2 有機泥の対策方法

表-1 石炭灰造粒物の化学成分およひ形状

\begin{tabular}{|c|l|}
\hline \multicolumn{1}{|c|}{ 形状 } & \multicolumn{1}{|c|}{ 化学成分 } \\
\hline \hline 長軸 $: 4 \mathrm{~cm}$ 程度 & $\mathrm{Si}_{2}: 44 \%$ \\
短軸: $3 \mathrm{~cm}$ 程度 & $\mathrm{Al}_{2} 0_{3}: 13 \%$ \\
タブレット形状 & $\mathrm{Ca} 0: 21 \%$ \\
& その他 (加がン9\%) $: 18 \%$ \\
\hline
\end{tabular}

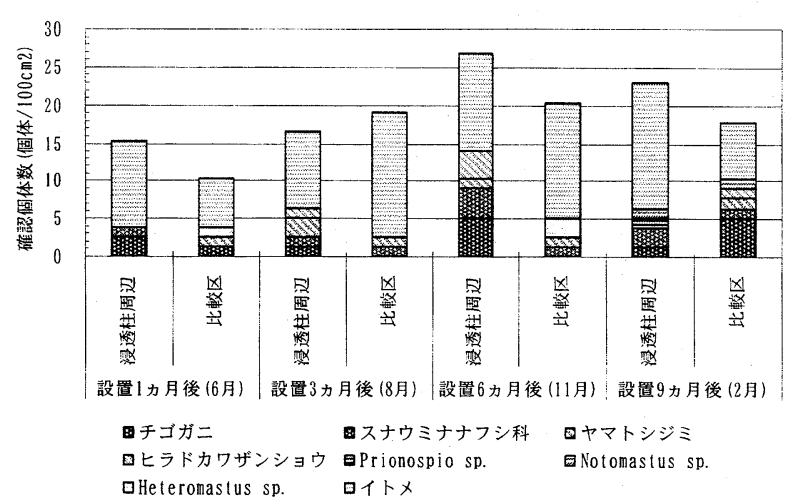

図-8＼cjkstart底生生物の季節変化

$75 \mu \mathrm{m}$ 以上の試料は日本工業規格JISに準拠し, 粒径 $75 \mu \mathrm{m}$ 未満の試料はレーザー回折式粒度分析測定装置 : SALD-2000J (島津製作所製)によって求めた.

c) 間隙水水質調査 (2層3地点 : 印, 月1回)

浸透柱周りの間隙水の水質を分析することで浸透柱に よる底質の改善効果を把握した. 採取にあたり, 現地の 底質を乱さないよう配慮し, 間隙水採取器を用いて実施 した. 採取試料は, アンモニア態窒素, 硝酸態窒素十亜 硝酸態窒素の分析に供した. アンモニア態窒素, 硝酸態 窒素十亜硝酸態窒素の分析は, 多項目水質/土袞/食品分 析計：DR4000型 (HACH社製) 用いて求めた.

d) 浸透柱内の流動調査 (1地点 : $\Delta$ 印, 1地点 : $\triangle$ )

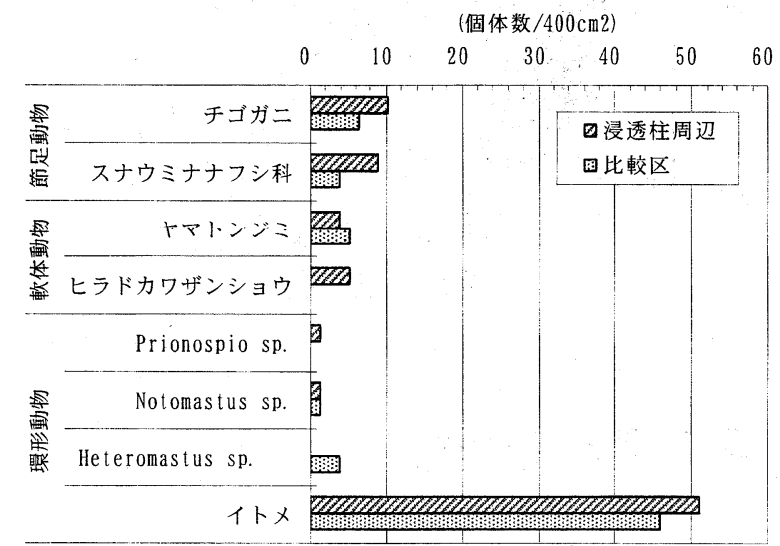

図-7 出現した底生生物とその数 (全期間の合計)

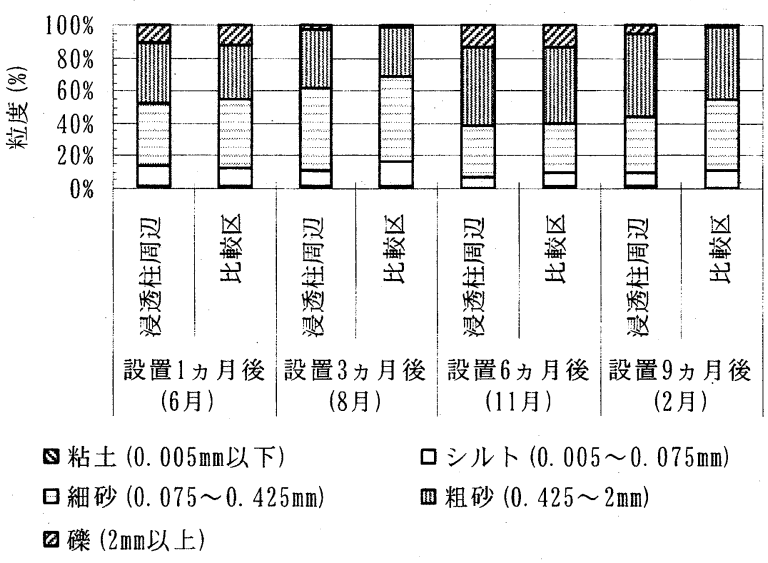

図-9＼cjkstart浸透柱設置後の粒度分布の変動

浸透柱内の流動は水温・塩分・水位関係から推定した. 浸透柱内に水位計：Compact-TD (アレック電子社製), 水温塩分計：Compact-CT (アレック電子社製) およびDO 計：Compact-DOW (アレック電子社製) を設置し，浸透 柱の上・中・下層水温, 直上塩分および浸透柱内の水位 およびDOを10分間隔で連続計測した．河川水位は，水 位計：Compact-TD (アレック電子社製) を図-6に示すよ うに設置し，10分間隔で連続計測した．さらに，11月に 浸透柱内にたまった粒子の粒度分析をレーザ一回折式粒 度分析測定装置 : SALD-2000Jを用いて求めた. 


\section{〈アンモニア態窒素〉}

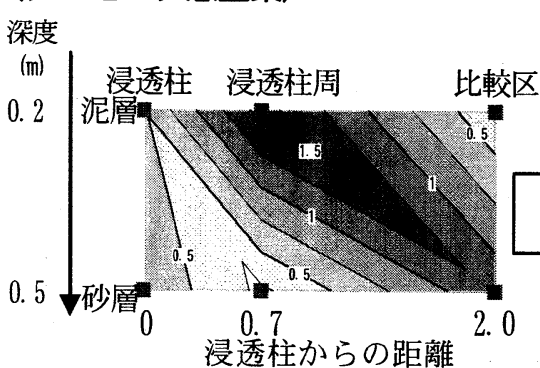

(a) -1 設置1力月後 (6月)

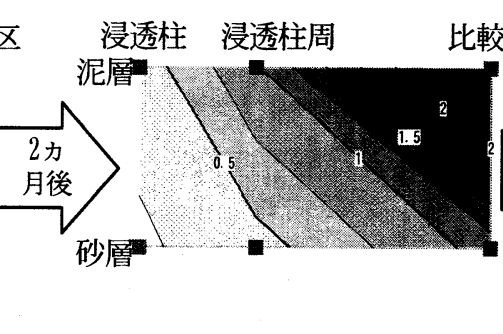

(b) -1 設置3力月後 (8月)

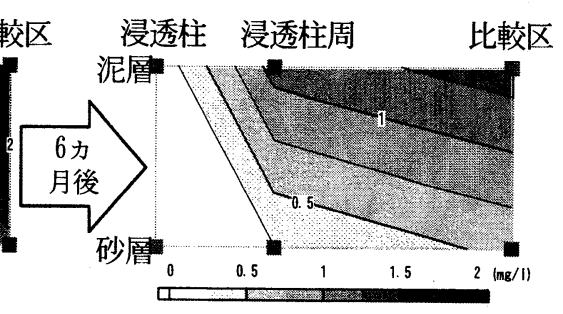

(c) -1 設置9力月後 (2月)

\section{〈硝酸態窒素十亜硝酸態窒素〉}

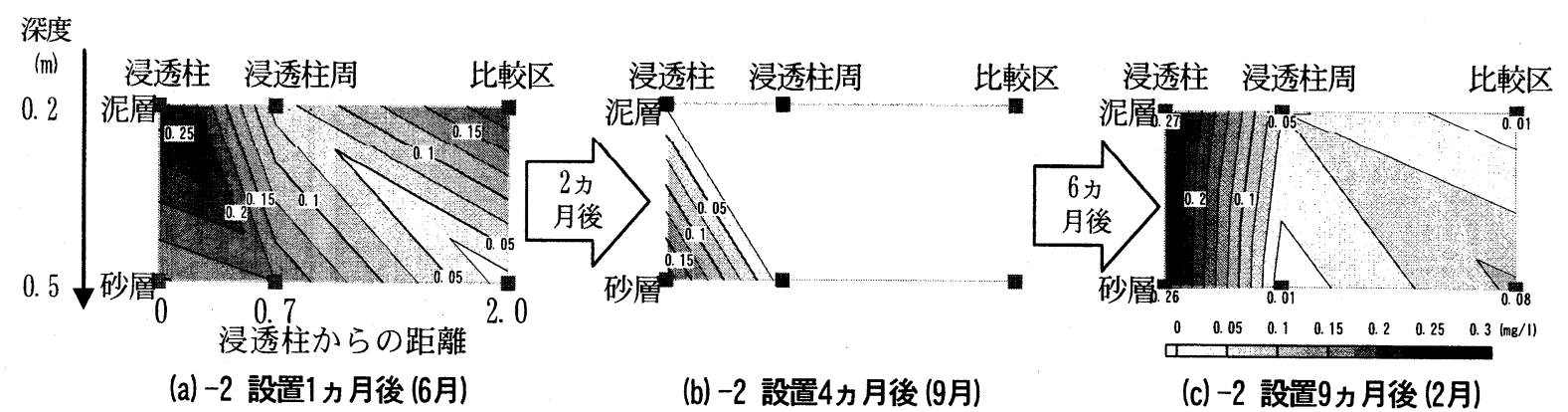

(a) -2 設置1力月後 (6月)

図-10 間隙水内栄養塩の分布変化

\section{3. 調査結果および考察}

\section{（1）底生生物の变化と粒度分布の状態}

図-7には4回の調查で出現した底生生物と出現数, 図一 8 には底生生物, 図-9には底質粒度の季節変化が示され ている. 図では, $100 \mathrm{~cm}^{2}$ あたりの生息個体数に換算し ている. 図-7より, 両地点ともイトメが優先し，生物種 に偏りがあることがわかる，底質の粒度は，細砂以下の 粒径が40\%以上を占めており, 生物の生息し難い環境で あることが伺える．夏季および秋季は，比較区で優占種 (イトメ)の割合が増加するのに対し，浸透柱周辺では, 節足動物 (チゴガニ), 軟体動物などが増加する傾向を示 している. ちなみに, 浸透柱内はカ二の生息場となって おり，浸透柱自体が生物生息場としての機能も有してい る (目視による観察) 。浸透柱の近傍ではシルト・粘土 の含有率が低下し，生物量は増大する傾向にある2)。浸 透柱から $50 \mathrm{~cm}$ 以上離れた点においても，比較区と比較 してチゴガニなどの節足動物や軟体動物の生息が多く確 認され, 浸透柱周辺で生物生息環境の改善が進行してい ると判断できる.

\section{（2）間隙水の水質変化と浸透柱周辺の還元状態の改善}

図-10に間隙水中の水質の経時変化（ (a) 1 ケ月後, (b) 3ケ月後, (c) 9ケ月後) を示す. アンモニア態窒素 は, 設置1ヶ月後で, 浸透柱周辺の泥層で最も高い值を 示していたが, 設置3ヶ月後には, 浸透柱で最も低く, 浸透柱から $0.7 \mathrm{~m}$ 離れた浸透柱周辺で高く(浸透柱より $0.5 \mathrm{mg} /$ 程度高()なり, 浸透柱から $2.0 \mathrm{~m}$ 離れた比較区で
最も高くなる (浸透柱より1.0〜2.0mg/高い) 傾向を示し た. 硝酸態窒素十亜硝酸態窒素は，設置4ヶ月後には，浸 透柱で最も高 $<$, 浸透柱周辺で $0.05 \mathrm{mg} /$ 以下の分布に なったが, 設置 9 ケ月後には, 浸透柱周辺の泥層でも $0.05 \mathrm{mg} /$ 程度の值を示すようになっている．これらの分 布は, 浸透柱周辺が酸化的な環境に遷移していることを 示している. また, アンモニア態窒素の砂層と泥層での 濃度を比較すると, 砂層で低い值を示していることから, 水循環は, 浸透柱と砂層間でも行われていること, 泥層 においても浸透柱に次いで浸透柱周辺で低い值を示して いることから, 浸透柱内を循環している水が泥層に浸透 し，還元状態が改善されていることが推定される.

\section{（3）浸透柱内における流れと泥中への酸素供給}

図-11には (a) 大潮期 (2004年12月25 27日) と (b) 小潮 期（2005年1月5〜7日）に計測された河川，あるいは浸 透柱内での水温変動と塩分変動（上段）, および水位と 溶存酸素濃度 (下段) を示している. 下層水温は浸透柱 下端から $5.5 \mathrm{~cm}$ で砂層と泥層の境界, 中層水温は下端か ら $25 \mathrm{~cm}$ ，直下水温は上端での水温を計測した.

なお, 干潮時の直上水温は気温を表しており, 気温は河 川水温に比較して数 ${ }^{\circ} \mathrm{C}$ 低くなっている. なお $\mathrm{DO}$ 計は大 気中では $12 \mathrm{mg} /$ 程度の值を示している.

この期間の河川水温は泥内水温よりも低く, 海水温は 泥内水温よりも高くなっており, 水温の基本分布は, 中 層, 下層, 直上の順に低くなっている. 大潮満潮時に暖 温な海水が遡上してくる期間には下層水温が上昇してい る. 上・中・下層水温の変化から, 下層には浸透水が堆 積泥層の下の砂層からの流入, 上層には遡上してきた海 水の下方への流入があり, 浸透柱へは上下端から河川水 


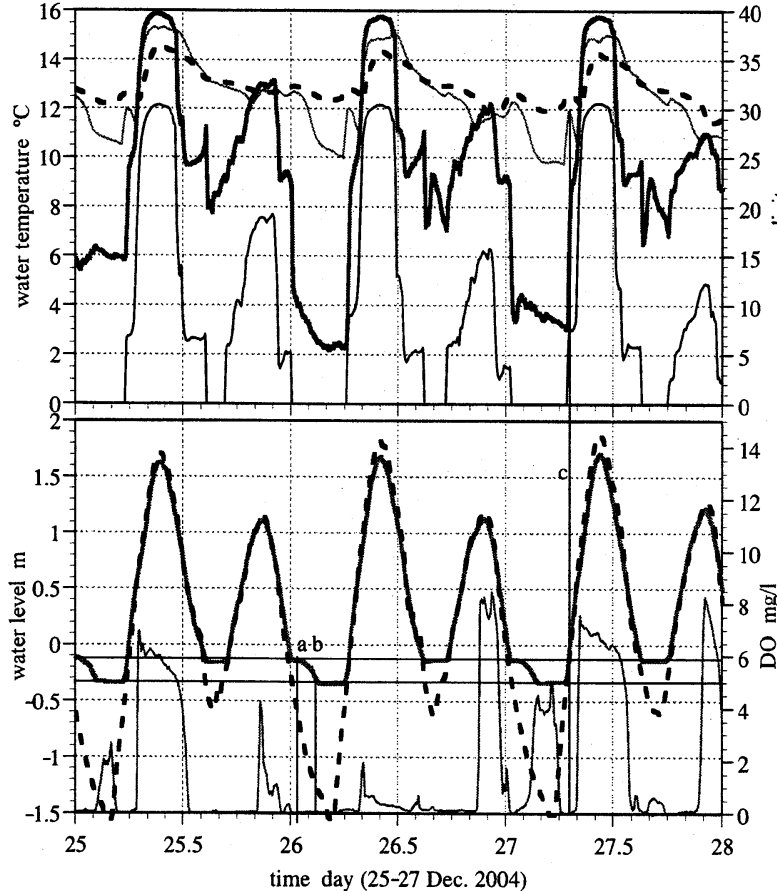

(a) 大潮期

注) 水位は，現地盤高を0mとする.

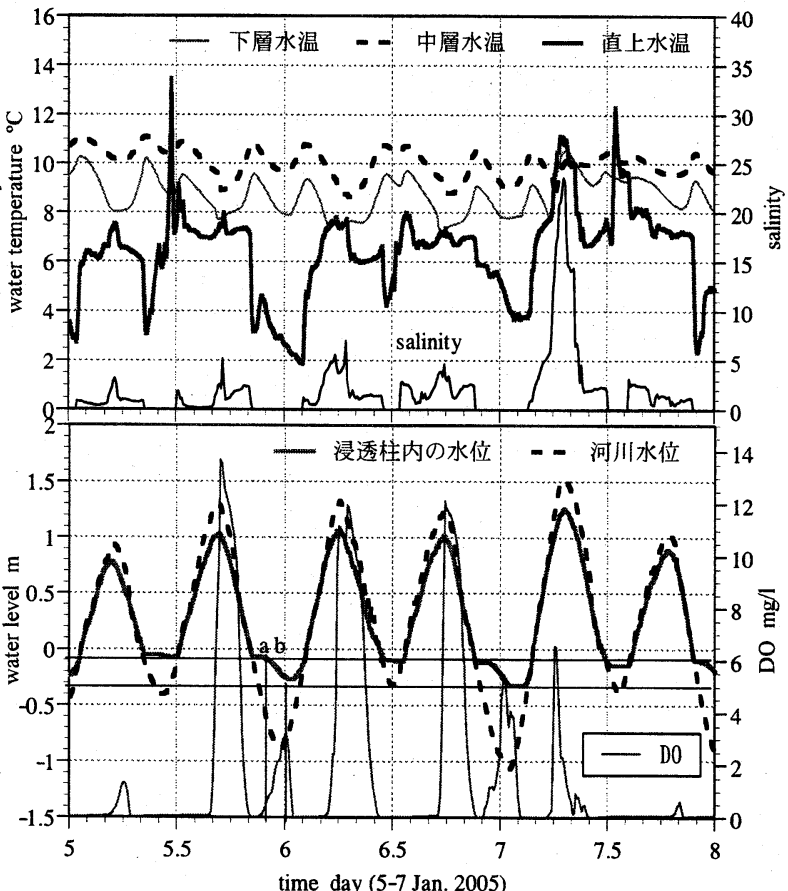

(b) 小潮期

図-11 河川 ·浸透柱内での水温変動と塩分変動および水位と溶存酸素濃度の関係

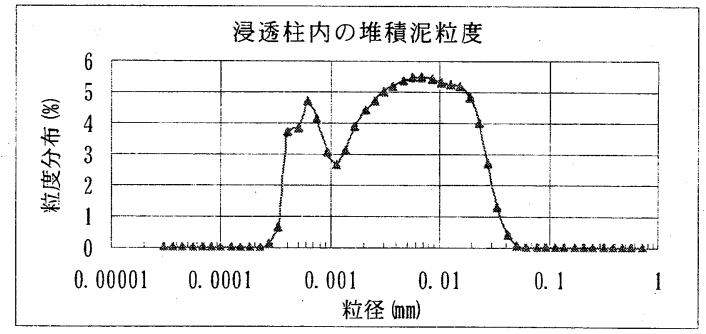

図-12 浸透柱内の堆積泥粒度 (平成16年12月25日〜1月25日)

が浸入していることがわかる.

a) 潮汐に伴う浸透柱内水位の変動（図11 (a)， (b) 参 照)

浸透柱内水位の変動は河川水位と浸透柱上端（以下， 現地盤とする）高との関係で決定される. 上げ潮開始後 における原地盤以深での浸透柱内水位の上昇が河川水位 の上昇と同時に起こっていることから，浸透柱下端から 河川水が流入していることがわかる．また，下げ潮期に おいては河川水位と約 $0.5 \sim 0.6 \mathrm{~m}$ 水位差が生じた時に 浸透柱内水位は低下速度が増し，約2時間で20〜30 $\mathrm{cm}$ 低 下している（時刻a，b）。なお，河川水位が-1.3m程度 になると浸透内水位は砂層まで下がるが，-0.6m程度で は最干時においても浸透中内には河川水が残留しており, 完全に排水される以前に上げ潮に変わり浸透柱内の水位 上昇は起こっている.

b) 干潟水没後のD0の変動特性（図11 (a)，（b) 参照）

DOの上昇は干潟水没後に起こっており, 浸透柱内で の流れ（横断面内での流動）が潮汐によって生起されて いることが推定される. 満潮位の高さによって浸透柱内 でのDOの上昇と満潮の現れる時間は異なっていること
がわかる. 水位の上昇量（海水の遡上）が大きい時には 満潮以前, 小さい時には満潮時にDOが高くなっている （どちらも水温の上昇に伴っている）特性を有している. DOの上昇と満潮時刻が潮位差の大きさによって異なる のは, 干潮時に河岸砂層内に残留する水量が異なるため と考えられる.

また，DOの急激な低下は，原地盤上の水位が $1 \mathrm{~m}$ 程度 以下になると起こっており, 満潮後, 数時間で浸透柱内 の圧力勾配（砂層内での流れ）がなくなっていることが 推定できる. 浸透柱内に流れが生じている間はDOの供 給が継続するために，DOの低下は小さいが流れがなく なった後にはDOの供給がなくなり, 堆積泥による消費 によってDOが急激に低下する.

c) 大潮期のD0供給（図11 (a) 参照)

大潮高潮期（1.5m以上）には，25を越える海水の流 入がある. 地盤が完全に没した後（浸透柱上約 $50 \mathrm{~cm}$ の 水位に達した時）塩分の上昇と共に急激なDO上昇が起 こっている. 浸透柱内が河川水で満たされた後にDOが 上昇するためには，DOを含む水塊が浸透柱内へ流入す る必要である. 
DOの急激な上昇が起こる直前まで下層水温が低下し (時刻c)，その後水温上昇とともにDOが上昇している. これは浸透柱内の水位上昇は，遡上海水を含んだ暖かい 浸透水が砂層（下端）から供給され，河川水位と位相な く上昇し（水温上昇）した後, 原地盤高まで干潟表層を 遡上してきた河川（海）水が浸透柱に流れ込んだ（水温 低下）ために起こったと考えられる. DOの上昇と上記 の水温変化を考えると, 浸透柱内には上端からDOを含 んだ水塊が流入していることが推定できる. さらに, 浸 透柱内では, 下端から上端に向かう流れも同時に生起し ていることから，上端からのDO供給が制限されること になる. 浸透柱内でのDOの上昇量が各満潮時に異なつ ているのは, 下端から浸透柱内への流入強さが異なるた めと考えられる。 上潮時のDO供給は, 潮位差による水 圧によって, 砂層内で地下浸透が生起され, 浸透柱内で の流動が継続していることで生じている.

\section{d) 小潮期のD0供給（図11 (b) 参照)}

原地盤上の水位が $1.2 \mathrm{~m}$ 以下では, 海水の遡上量は少 なく, 塩分は最大で5の上昇にとどまっている. 塩分上 昇が5以下の海水遡上では, 下層・中層水温の逆転は起 こらないこと, 中層・下層水温は浸透柱上の水位変動と 対応していることがわかる，満潮時に水温が低く，下げ 潮に伴って水温が上昇しているが，河川水位が浸透柱内 水位のより低くなる場合は, 浸透柱内の水位低下に伴っ て水温が低くなっている. 上げ潮に伴う水温低下は, 浸 透柱内に低水温の（海水流入の少ない）河川水が流入す るためである. 浸透柱内水位の低下に伴う水温低下は, 空気塊が浸透柱内に流入するためである.

急激なDOの上昇は, 満潮時に起こっている. DOの上 昇が起こる直前まで中層水温が低下し（この時は下から 上方向への流れ，水温差に勾配がない），その後, 水温 上昇とともにDOが上昇している（上から下方向への流 れ）ことから，小潮期においても大潮期と同様にDOの 上昇は上層からの海水流入に依るものと考えられる.

e）水平面内での流れ（図11 (b) 参照)

河川水位が現地盤以下になる時間に浸透柱内水位の上 昇が起こると, 水位上昇と同時に下・中層とも水温の上 昇が起きている. これは浸透柱内の水位上昇時に供給さ れる浸透水か暖かいことを示している. しかし, 水温は 中層で高い分布となっていることから, 単純に砂層 (下 端）からの流入によって浸透層内の水温が上昇すること は起こらない，中層で水温が上昇するためには, 側方か らの流入が必要であることから, 浸透柱内の水位上昇初 期には, 浸透柱への側方流動が起こっていることが推定 できる.

\section{（4）浸透柱内での有機泥の分解・無機化}

図-12には2004年12月25日～2005年1月25日間に浸透柱 内に流入・残留した粒子の粒度分布が示されている.

浸透柱内に流入した粒子は, シルト・粘土質であるこ とがわかる. これらの有機泥は上端部から海水によって 運ばれるか，あるいは，側岸からの流出が考えられる。
なお対象域で別に行っているセジメントトラップ調査で は, 約 $2 \mathrm{~g} / \mathrm{m}^{2} / \mathrm{h}$ の有機泥の沈降があることがわかってい る . 浸透柱内は好気的な状態が保たれていることから 浸透柱内では, 分解・無機化が急速に進むことが予想さ れる. 浸透柱内での有機泥の分解・無機化の効率や細粒 分の挙動については, 長期の実験が必要であり, 今後こ れらの点について検討していく.

\section{4. おわりに}

石炭灰造粒物を用いた底質改善技術の有効性を評価 することを目的に, 浸透柱周辺および比較区において底 生生物の生息状況と底質粒度の関係, 底泥中の間隙水質 の変化, および浸透柱内の流動について検討した.

以下に本実験結果をまとめる.

(1) 浸透柱を設置することにより, 浸透柱内での流動が 促進される. この流れにより, 浸透柱の周辺数 $10 \mathrm{~cm}$ 以上にわたり, 泥層が還元状態に改善されているこ とが確認された。

(2) 現地の底質粒度は, 細砂以下の粒径が40\%以上を占 めており，比較的生物の生息しにくい環境であるが， 浸透柱周辺で確認された底生生物は, チゴガニなど の節足動物や軟体動物の生息が多く確認され, 生物 の生息環境が改善されていると考えられる.

(3) 浸透柱内の流動は, 浸透柱が河川水で満たされた後 にも, 砂層内で地下浸透が生起され生じる. この流 れよって浸透柱内に酸素が供給されていることがわ かった.

(4) 浸透柱内へは上下端からの河川水の流入のみではな く, 側方からの流入も確認された. 側方流動がある ことによって浸透柱周辺の底泥浄化が期待される.

(5) 浸透柱内は好気的な状態が保たれていることから, 浸透柱内では分解・無機化が急速に進むここが期待 される. 浸透柱内での有機泥の分解・無機化の効率 や細粒分の挙動については, 今後の検討課題である.

\section{謝辞}

本実験は, 社団法人中国建設弘済会「技術開発支援制 度」に基づく助成を受けて害施されたものである. 記し て，ここに謝意を表す。

\section{参考文献}

1）日比野忠史 : 河口域での有機物の循環と生物生息 場の形成, 水系環境の保全と創造-自然再生に向け て-講演集, pp. 2-2-1〜2-2-12, 2004.

2）石炭灰による底泥処理実験事前調査報告書, 2003.

3) 富田智, 長戸宏樹, 日比野忠史, 西牧均, 松本英 雄 : 太田川河口域における有機泥の挙動に関する 研究, 水工学論文集, 第 49 巻 (2), pp. 14111416, 2004. 